\title{
PENTINGNYA KESADARAN HUKUM DAN PERAN MASYARAKAT INDONESIA MENGHADAPI PENYEBARAN BERITA HOAX COVID-19
}

\author{
Nabila Farahdila Putri ${ }^{1}$ \\ Universitas 17 Agustus 1945 Surabaya \\ Email:nabilafa87@gmail.com \\ Ellin Vionia ${ }^{2}$ \\ Universitas 17 Agustus 1945 Surabaya \\ Email: ellinakse@gmail.com \\ Tomy Michael ${ }^{3}$ \\ Universitas 17 Agustus 1945 Surabaya \\ Email: tomy@untag-sby.ac.id \\ DOI: https://doi.org/10.31764/mk:\%20jih.v11i1.2262
}

Received: Feb 1, 2020, Accepted: Feb 27, 2020 /Published: April 30, 2020

\begin{abstract}
Currently in Indonesia is being hit by corona virus, corona virus is a new disease called Covid-19. There are a lot of news about corona virus, even in this condition there are still many hoaxes or fake news events. With current technological developments, the spread of hoax news is very easy to occur through social media, namely the internet. In this journal the focus is on the problem of spreading false news related to covid-19 and the role of the public in fighting hoax news with digital literacy. This research method uses empirical research methods and content analysis related to hoax news dissemination. The purpose of this study explains the efforts to the public to deal with hoax news related to covid-19 with digital literacy. The novelty of the research in this study the researcher connects public awareness with legal responsibility for the perpetrators of hoax news dissemination. The results of this study, show that literacy culture through articles, YouTube makes it easier for people to identify hoax news. Digital literacy culture is a solution to avoid hoax news. Then the importance of the role of the community in facing the spread of hoax news so as not to harm themselves and others legally and socially.
\end{abstract}

Keywords: covid-19, hoaxes, digital literacy, legal awareness

\begin{abstract}
Abstrak
Saat ini di Indonesia sedang dilanda corona virus, corona virus merupakan penyakit baru yang disebut dengan istilah Covid-19. Banyak berita yang mengangkat topik corona virus, bahkan dalam kondisi seperti ini masih banyak peristiwa penyebaran berita hoax atau berita palsu. Dengan perkembangan teknologi saat ini, penyebaran berita hoax sangat
\end{abstract}


gampang terjadi melalui media sosial yaitu internet. Dalam jurnal ini memfokuskan pada permasalahan penyebaran berita palsu yang terkait covid-19 dan peran masyarakat dalam menghadapi berita hoax dengan literasi digital. Metode penelitian ini menggunakan metode penelitian empiris dan content analysis terkait penyebaran berita hoax. Tujuan penelitian ini menjelaskan upaya kepada masyarakat untuk menghadapi berita hoax terkait covid-19 dengan literasi digital. Kebaruan riset dalam penelitian ini peneliti menghubungkan kesadaran masyarakat dengan tanggung jawab hukum atas pelaku penyebaran berita hoax. Hasil penelitian ini, menunjukkan banhwa budaya literasi melalui artikel, youtube membuat masyarakat lebih mudah dalam mengidentifikasi berita hoax. Budaya literasi digital menjadi solusi untuk menghindari berita hoax. Kemudian pentingnya peran masyarakat menghadapi penyebaran berita hoax agar tidak merugikan diri sendiri dan orang lain secara hukum dan sosial.

Kata kunci: covid-19, hoax, kesadaran hukum, literasi digital

\section{PENDAHULUAN}

Saat ini di Indonesia sedang dilanda corona virus. Corona virus belum diketahui secara benar dari mana virus tersebut berasal. Corona virus merupakan penyakit baru yang disebut dengan istilah Covid-19 ${ }^{1}$. Virus ini sangat membahayakan karena menjangkit hampir semua negara secara bersamaan dan virus ini dapat menular dengan cepat dari manusia satu ke manusia lainnya melalui benda-benda sekitar. Sehingga virus ini sangat meresahkan masyarakat dan virus ini dapat berujung kematian. Banyak berita yang mengangkat topik corona virus dengan kabar terbaru setiap harinya. Berita berita mulai bermunculan bahkan masih saja terjadi peristiwa belum diketahui kebenarannya bahkan juga bisa disebut sebagai berita palsu. Hoax dapat diartikan berita palsu yang memiliki maksud untuk dijadikan bahan lelucon. ${ }^{2}$ Sebuah berita atau kabar palsu yang mempunyai tujuan untuk menipu serta memprovokasi pembaca dan

\footnotetext{
${ }^{1}$ World Health Organization, Novel Coronavirus 2019, url: https://www.who.int/emergencies/diseases/novel-coronavirus-2019, diakses pada 15 Mei 2020.

2 Juditha, Christiany, Interaksi Komunikasi Hoax di Media Social serta Antisipasinya, Jurnal Pekommas. Volume. 3 Nomor 1, April 2018, url: https://media.neliti.com/media/publications/261723-hoax-communication-interactivity-in-soci2ad5c1d9.pdf, diakses tgl 15 Mei 2020.
} 
pendengarnya agar mempercayai berita atau kabar palsu tersebut, padahal sang pembuat berita palsu tersebut tahu bahwa berita atau kabar yang dibuatnya tidak benar. ${ }^{3}$

Penyebaran berita hoax membawa dampak kepada masyarakat, dampak yang terjadi yaitu dampak negatif karena berita hoax ini membawa kekhawatiran, kesalahpahaman, kegaduhan sehingga masyarakat banyak yang dirugikan dengan adanya berita tersebut dan merupakan pembodohan bagi yang mengonsumsinya. Hoax juga sebagai cara untuk pengalihan isu, pemecah belah, penipuan publik. Penyebaran berita hoax banyak dilakukan oleh orang yang tidak bertanggung jawab, bahwa orang tersebut mengerti berita tersebut merupakan sebuah kebohongan dan secara sadar menyebarkan berita palsu tersebut agar mendapat perhatian, menggiring opini publik. Dengan perkembangan teknologi saat ini, penyebaran berita hoax sangat gampang terjadi melalui media sosial, yaitu internet melalui artikel, whatsapp, instagram, line, facebook. Di Indonesia banyak warganya yang merupakan pengguna aktif media sosial dan pertumbuhan pengguna internet dapat menimbulkan dampak untuk tempat menyebarkan informasi atau berita yang belum tentu kebenarannya. Karena dalam media sosial manusia bisa berinteraksi dengan banyak orang sehingga tiap individu atau komunitas dengan mudah menyampaikan berbagai opini dan masih banyak orang yang tidak kritis atau hati hati dalam menyampaikan informasi. Dan juga masih banyak masyarakat yang kurang waspada dan kritis dalam menerima informasi. Beberapa berita hoax terkait Covid-19 ini diantaranya penularan virus corona melalui angin, dimana terdapat 59 Jemaat Gereja Tewas

3 Simarmata, Janner,dkk, Hoaks dan Media Sosial: Saring Sebelum Sharing, Yayasan Kita Menulis, Jakarta, 2019, hlm. 37. 
setelah meminum Dettol demi mencegah Covid-19, Penyembuhan Virus Corona dengan Bawang Putih. ${ }^{4}$

Berdasarkan hal tersebut, penelitian ini berusaha untuk dapat menginformasikan bahaya yang terjadi, jika penyebaran berita hoax mengenai Covid-19 terus terjadi dan peran masyarakat sangat berpengaruh terhadap penyebaran berita hoax sehingga pentingnya edukasi dalam penelaahan berita mengenai Covid-19 ini. Kebaruan riset dalam penelitian ini yaitu peneliti turut melakukan penjelasan terhadap pasal hukum yang dilakukan atas tanggung jawab atas penyebaran berita hoax yang terjadi sehingga pelaku penyebaran berita hoax ini tidak hanya merugikan masyarakat Indonesia tetapi pemerintah pun menjadi aktor yang dirugikan atas penyebaran berita hoax tersebut.

Perbandingan penelitian pertama menghasilkan bahwa pihak yang bertanggung jawab atas penyebaran berita hoax adalah individu itu sendiri, pihak keluarga, dan pihak pemerintah ${ }^{5}$. Karena penyebaran yang dilakukan atas tanggung jawab dan niatan dari dalam diri sehingga peneliti setuju dalam permasalahan ini. Karena diri pribadilah yang menjadi instrumen utama dalam penyebaran berita hoax. Perbedaan penelitian ini dengan peneliti yakni kasus yang di kaji dalam penyebaran berita hoax untuk dapat mengubah kebijakan dan ingin menjadi pihak utama yang menyebarkan tanpa adanya cross check terlebih dahulu. Penelitian kedua menjelaskan bahwa media sosial menjadi saluran penyebaran berita hoax tertinggi sehingga pihak utama dalam penyebaran berita hoax ini sulit untuk disaring karena mudah tersebar. Hal ini didukung oleh Kementerian Komunikasi dan Informatika Republik

\footnotetext{
4 __ Another Pastor Strikes, "Makes Congregants Drink Dettol", url: https:/ / citizen.co.za/news/south-africa/1371173/another-pastor-strikes-makes-congregantsdrink-dettol/, diakses tgl 13 Mei 2020

5 Dedi Rianto Rahadi, "Perilaku Pengguna dan Informasi Hoax di Media Sosial", Jurnal Manajemen $\&$ Kewirausahaan, Volume. 5 Nomor. 1, 2017, url: http://jurnal.unmer.ac.id/index.php/jmdk/article/view/1342, diakses tgl 13 Mei 2020.
} 
Indonesia yang memblokir 300 situs dan media sosial yang merugikan banyak pihak terutama penyebaran berita hoax. ${ }^{6}$ Penelitian yang dilakukan oleh peneliti lebih berfokus terhadap peran masyarakat Indonesia dalam menghadapi penyebaran berita hoax sehingga dalam penelitian ini dapat mendukung bahwa media online dan media sosial pengaruh yang besar dalam penyebaran berita hoax dan mendukung Undang-undang ITE. Penelitian ketiga lebih mengarah kepada bahaya berita hoax dan pengaruhnya terhadap toleransi bermasyarakat. Hal ini menjadikan kebebasan berpendapat jika disalah artikan dapat menjadi bumerang bagi masyarakat sekitar sehingga menimbulkan dampak tidak nyaman munculnya ujaran kebencian, provokasi, dan hasutan kepada individu atau kelompok lainnya. ${ }^{7}$ Penelitian ini dapat mendukung penelitian yang dilakukan karena bahaya berita hoax akan berpengaruh terhadap sikap toleransi akan sesama manusia. Terutama dalam pandemik Covid-19 ini sikap dan perilaku masyarakat memiliki pengaruh terhadap penyakit ini.

Dengan demikian, berdasarkan penelitian diatas memiliki relevansi yang sesuai dengan penelitian yang dilakukan sehingga peneliti merumuskan satu rumusan masalah yakni bagaimana peran masyarakat dalam menghadapi berita hoax terkait Covid-19 dan tanggung jawab hukum atas penyebaran berita hoax tersebut. Dalam penelitian ini bertujuan untuk menjelaskan sekaligus menganalisis pentingnya peran masyarakat dalam menghadapi berita hoax terkait Covid-19.

\footnotetext{
6 M. Ravii Marwan, Ahyad, Analisis Penyebaran Berita Hoax di Indonesia. Jurnal Nasional. Volume. 1 Nomor. 1 , 2018, http://ravii.staff.gunadarma.ac.id/Publications/files/3552/ANALISIS+PENYEBARAN+BERITA+ HOAX++DI+INDONESIA.pdf, diakses tgl 13 Mei 2020.

7 Alief Sutantohadi, Rokhimatul Wakhidah, Bahaya Berita Hoax dan Ujaran Kebencian pada Media Sosial Terhadap Toleransi Bermasyarakat, Jurnal Pengabdian Kepada Masyarakat. Volume. 1, Nomor. 1, http://journal.pnm.ac.id/index.php/dikemas/article/download/153/75, diakses tgl 13 Mei 2020.
} 


\section{METODOLOGI}

Penelitian ini disusun menggunakan metode penelitian kualitatif empiris dan menggunakan tipe penelitian content analysis atas laporan pemberitaan media terkait penyebaran hoax atau berita palsu terkait Covid-19. Metode ini menggunakan data sekunder dan atau bahan hukum sekunder seperti artikel, berita, dan jurnal untuk dapat mengetahui dan memperjelas penelitian yang dilakukan. ${ }^{8}$ Penelitian ini akan memfokuskan untuk mendapatkan informasi berdasarkan data dari buku, literatur, penelitian ilmiah bahkan perundang-undangan yang dapat mendukung penelitian.

\section{PEMBAHASAN}

Berita hoax saat ini sangat mudah di percaya oleh masyarakat, apalagi dengan kemajuan teknologi semakin hari semakin canggih mengakibatkan menyebarnya berita hoax lebih cepat. Kemajuan teknologi disaat ini memberikan dampak negative dan positif, satu sisi mengakses informasi secara lebih cepat dan lebih mudah, namun disisi yang lain bisa memberikan masalah dalam hubungan sosial yang pastinya akan berpengaruh pada masa depan bangsa, apalagi dengan gencarnya berbagai macam informasi yang tidak tersaring. Kejadian tersebut terjadi karena kurangnya edukasi literasi digital. Dalam usaha menangkal beritaberita hoax, pemerintah membuat berbagai program yang dapat membuat masyarakat agar berpikir kritis dalam mendapat dan membaca informasi yang diterima yaitu melalui budaya literasi. Budaya literasi sangat penting dilakukan agar masyarakat dapat menyaring suatu kabar atau berita palsu yang diterimanya.

Untuk itu upaya dalam menangani penyebaran berita hoax dengan membiasakan budaya literasi harus dilakukan untuk menghindari

\footnotetext{
8 Peter Mahmud Marzuki, Penelitian Hukum Cetakan 2, Kencana, Jakarta, 2008, hlm. 58.
} 
kerugian-kerugian dalam masyarakat yang disebabkan oleh berita hoax tersebut. Pemerintah juga sudah terus berupaya dengan adanya kebijakan-kebijakan dan aturan-aturan dalam menangani penyebaran berita hoax atau palsu dengan menyusun peraturan yang terdapat sanksi yang tegas didalamnya bagi pengguna internet yang dalam menggunakannya tidak patut atau negatif. Salah satu bentuk kebijakan pemerintah yaitu dengan pemblokiran situs yang bermasalah (situs yang menyebarkan hoax atau berita palsu tidak dapat diakses lagi, pembentukan Badan Siber Nasional, Kerjasama dengan Dewan pers, Kerjasama dengan Facebook. Literasi tidak sekedar untuk baca saja namun komprehensif. Beberapa masyarakat yang rajin membaca, menganggapnya sebagai kebutuhan. Jenis bacaan ini dapat berupa media cetak seperti koran, majalah maupun media elektronik seperti Televisi.

Bahwa kita belum sepenuhnya memanfaatkan media untuk mendapatkan informasi dan menambah pengetahuan. Sehingga jenis bacaan melaui media elektronik di zaman kemajuan teknologi semakin canggih seperti saat ini merupakan hal yang mudah dalam memperoleh informasi. Literasi menjadikan manusia lebih berguna dalam masyarakat, di karenakan kemampuan untuk menyelesaikan suatu masalah melalui berpikir kritis dari kebiasaan membaca. Selain itu, literasi juga menjadi atasapresiasi budaya.

Berikut ada beberapa cara yang dapat kita lakukan untuk mengidentifikasi berita hoax:

1. Melihat siapa yang mengunggah informasi tersebut sehingga kita tahu kebenaran dari berita tersebut, karena jika berita tersebut berasal dari media-media ternama akan memiliki kredibilitas yang tinggi sehingga akan berhati-hati dalam melakukan penulisan.

2. Cari sumber pembanding pada saat kita ragu berita yang kita baca hoax atau tidak, kita dapat mencari informasi dari sumber lain. Terutama 
pada referensi atau media lain agar dapat melihat apakah berita yang ada pada internet sejalan dengan berita yang ada di televisi.

3. Lihat situs media yang dikunjungi. Jika situs tersebut mencurigakan dan tidak terverifikasi dan terkesan abal-abal segera tinggalkan.

4. Periksa fakta Berita tersebut berasal dari mana? Sumbernya siapa? Apakah dari institusi resmi? Sebaiknya jangan cepat percaya ketika membaca berita tersebut. Apabila terdapat berita pada artikel yang dapat diedit oleh siapapun maka berita tersebut belum sepenuhnya dapat dipercaya Maka perhatikan keaslian sumber berita.

5. Cek keaslian foto, karena saat ini teknologi semakin canggih sehingga surat, artikel, foto maupun video dapat dipalsukan. Sehingga timbul adanya kerugian dalam masyarakat.

\section{A. Pentingnya Literasi Digital Saat Pandemi Covid-19}

Literasi digital menjadi salah satu upaya yang dapat dilakukan bagi masyarakat Indonesia dalam menghindari penyebaran hoaks. Upaya-upaya yang dapat dilakukan dalam melawan penyebaran berita hoax terkait Covid-19 dengan budaya membaca pada literasi digital adalah dapat melalui:

a. Melalui artikel-artikel resmi yang ada pada internet

b. Melalui informasi atau berita resmi yang ada pada channel di youtube

Terdapat contoh kasus yang peneliti ambil yaitu terkait Virus Corona atau Covid-19 yang saat ini sedang gencar dan menjadi permasalahan di seluruh dunia. Dari update terakhir, Menteri Komunikasi dan informatika mengatakan bahwa hingga saat ini terdapat 560 isu dan penyebaran hoax terkait Covid-19 yang sudah terdeteksi. Setelah mendeteksi hoax tersebut, Kominfo meminta platform media sosial untuk melakukan takedown hoax yang ada pada media sosial beberapa diantaranya terdapat pada facebook, twitter, dan 
Instagram. Dari jumlah tersebut, persebarannya mencapai 1.222 di 4 platform digital yang beberapa diantaranya sudah di takedown ${ }^{9}$.

Sementara itu untuk pencegahan penyebaran hoax terkait Covid19, kominfo menyatakan perlu adanya edukasi dan literasi digital kepada masyarakat terkait kerugian dari hoax. Karena akibat dari berita hoax tentang corona ini menimbulkan kekhawatiran dalam masyarakat sehingga dengan adanya edukasi dan literasi kepada masyarakat, masyarakat mampu untuk memerangi berita hoax dengan membaca serta mencari informasi dari sumber terpercaya dan meminimalisir masyarakat yang menjadi korban berita hoax .

Misal saja pada artikel-artikel dan maupun media sosial lainnya apabila terdapat postingan terkait isu hoax mengenai covid-19 bisa ditindak lanjuti dengan melaporkan akun media sosial tersebut. Karena isu hoax juga menyebabkan kekhawatiran pada masyarakat seperti terjadinya panic buying, masyarakat berbondong-bondong membeli masker dengan jumlah yang banyak dan kebutuhan pokok lainnya sehingga mereka terkesan khawatir akan permasalahan yang terjadi melalui budaya membaca dari literasi digital yang telah dijelaskan tadi, karena lewat budaya membaca tersebut membuat kita lebih mudah dalam mengidentifikasi berita hoax. Sehingga isu-isu hoax yang beredar tidak mudah di percaya karena sudah mengetahui kebenarannya.

\section{B. Kasus Berita Hoax Terkait Covid-19 di Indonesia}

Seorang warga di kabupaten Bondowoso harus berurusan dengan polisi karena mengunggah berita bohong soal virus corona di facebook. Karena mengunggah berita bohong mengenai corona di facebook dan pelaku di tetapkan sebagai tersangka dan terancam hukuman penjara. Pelaku mengunggah video iring-iringan mobil polisi

$9 \longrightarrow$ Menkominfo: Ada 554 Isu Hoax soal Covid-19, 89 Orang Jadi Tersangka, https://news.detik.com/berita/d-4982087/menkominfo-ada-554-isu-hoax-soal-covid-19-89-orangjadi-tersangka. Diakses pada tanggal 13 Mei 2020. 
yang keluar dari terminal Bondowoso viral di media sosial setelah di unggah ke akun facebook pelaku, pengungah juga menyertakan keterangan bahwa video ini adalah upaya penanganan penyelamatan seorang tenaga kerja wanita yang positf terkena covid 19, padahal faktanya mobil iring-iringan polisi itu adalah kegiatan kerja bakti polisi di terminal bus Bondowoso. Poisi bergerak cepat menangkap pemilik akun bernama "SFH" warga Jambi Sari, Bondowoso. Karena memposting virus corona sudah masuk Bondowoso, tulisan tersebut dimuat di konten pelaku di facebook sehingga dampaknya sangat luar biasa meresahkan masyarakat Bondowoso. Atas perbuatannya tersangka akan dijerat pasal 46 UU tentang Informasi dan transaksi elektronik dengan hukuman maksimal 6 tahun penjara ${ }^{10}$.

\section{Tanggung Jawab Hukum Atas Penyebar Berita Hoaks}

Pemerintah Indonesia menetapkan bahwa penyebaran berita hoax dapat dijatuhi Pidana sesuai dengan Pasal 14 dan 15 UU Nomor 1 Tahun 1946. ${ }^{11}$ Hukuman yang diatur dalam Pasal 14 dan 15 UU 1/1946 ini dikualifikasi pada tiga bentuk pelanggaran, yakni:

Tabel 1:

Sanksi Hukum Pidana Bagi Penyebar Hoax

\begin{tabular}{|c|c|c|c|}
\hline No. & Kualifikasi Penyebaran Berita Hoax & Sanksi & Dasar Hukum \\
\hline 1. & $\begin{array}{llr}\text { Menyebarkan } & \text { berita hoax dengan } \\
\text { sengaja dalam kesadaran diri yang } \\
\text { menimbulkan } \\
\text { Masyarakat }\end{array}$ & 10 Tahun & Pasal 14 ayat (1) \\
\hline 2. & $\begin{array}{l}\text { Menyebar luaskan berita hoax dengan } \\
\text { menimbulkan kekhawatiran dan } \\
\text { kecemasan di Masyarakat, dan pelaku } \\
\text { menyengka mengenai berita yang di } \\
\text { sebarluaskannya }\end{array}$ & 3 Tahun & Pasal 14 ayat (2) \\
\hline
\end{tabular}

\footnotetext{
$10 \quad$ Penyebaran Hoaks Virus Covid-19 Ditangkap Polisi, https://www.youtube.com/watch?v=2C-92kAUzaQ, diakses pada tanggal 13 Mei 2020.

11 Undang-Undang No.1 Tahun 1946 Tentang Peraturan Hukum Pidana Undang-Undang Informasi dan Transaksi Elektronik
} 


\begin{tabular}{|c|c|c|c|}
\hline 3. & $\begin{array}{l}\text { Menyebar luaskan berita yang tidak } \\
\text { memiliki validitas yang tepat dan } \\
\text { berlebihan dan tidak lengkap. Disisi } \\
\text { lain pelaku memahami dan telah } \\
\text { mengira bahwa berita itu akan } \\
\text { menimbulkan kekhawatiran di } \\
\text { masyarakat }\end{array}$ & 2 tahun & Pasal 15 \\
\hline
\end{tabular}

Sumber Data : Data diolah berdasarkan ketentuan Undang-Undang No.1 Tahun 1946 Tentang Peraturan Hukum Pidana Undang-Undang Informasi dan Transaksi Elektronik.

Berdasarkan pasal 14 dan 15 UU 1/1946 penyebar berita hoax memiliki kriteria tersendiri dalam tujuan dan maksudnya. Ketiga kriteria diatas memiliki sanksi pidana mulai dari 4-6 Tahun dengan denda maksimal Rp 750 juta hingga Rp. 1 miliar berdasarkan UU No. 19 Tahun 2016 tentang Perubahan Atas UU No. 11 Tahun 2008 tentang Informasi dan Transaksi Elektronik (ITE) ${ }^{12}$.

Tabel 2:

Dasar Hukum Penyebar Hoax

\begin{tabular}{|c|l|c|}
\hline NO & \multicolumn{1}{|c|}{ Muatan Konten } & Dasar Hukum \\
\hline 1. & Pencemaran nama baik atau fitnah & Pasal 27 ayat (3) \\
\hline 2. & $\begin{array}{l}\text { Penipuan untuk motif ekonomi } \\
\text { yang merugikan konsumen }\end{array}$ & Pasal 28 ayat (1) UU ITE \\
\hline 3. & Provokasi terkait sara & Pasal 28 ayat (2) UU ITE \\
\hline
\end{tabular}

Berdasarkan dasar hukum tersebut penyebar hoax dalam jenis kegiatan yang dilakukannya memiliki dasar hukum pada Pasal 27 dan 28 dengan ayat yang berbeda untuk aktor yang melakukan pelanggaran tersebut. Kategori ini dilakukan untuk memisahkan penyebaran hoax

\footnotetext{
12 Hamalatul Qur'ani, Pasal Berlapis Bagi Penyebar Berita Hoax, https://www.hukumonline.com/berita/baca/1t5b051b504cf5b/ pasal-berlapis-bagi-penyebarberita-hoax/, Diakses pada tanggal 13 Mei 2020.
} 
dengan landasan yang berbeda seperti provokasi, pencemaran nama baik, dan penipuan yang merugikan kosumen. Dengan demikian, penyebaran berita hoax di Indonesia memiliki payung hukum/dasar hukum atas tanggung jawab hukum yang dilakukannya. Penyebar berita hoax tidak hanya merugikan masyarakat Indonesia, tetapi turut merugikan pemerintah Indonesia dan segenap komponennya sehingga tindak penyebaran berita hoax di Indonesia memiliki rentan waktu 2 sampai 10 tahun tindak pidana.

\section{SIMPULAN}

Peran masyarakat dalam menghadapi penyebaran berita hoax dengan melakukan pemilahan dan penyaringan informasi yang didapatkan sehingga masyarakat tidak terjerumus kedalam berita yang tidak benar. Pentingnya literasi digital dilakukan oleh setiap elemen masyarakat sehingga penyebaran berita hoax dapat diminimalisirkan. Tindakan penyebaran berita hoax di Indonesia sudah memiliki dasar hukum dan tanggung jawab hukum dengan waktu penjara 2 sampai 10 tahun tergantung kategori permasalahan yang dilakukan. Pentingnya peran masyarakat dalam menghadapi penyebaran berita hoax yang tentunya merugikan diri sendiri dan orang disekitarnya, karena penyebaran berita hoax terutama dalam pandemi Covid-19 ini memiliki konsekuensi yang besar dalam kasusnya. Masyarakat dituntut untuk dapat selalu mencari dan memilah informasi yang baik untuk dapat dicerna dengan seksama. Budaya literasi sekaligus memilah informasi yang didapatkan masyarakat agar terhindar dari penyebaran berita hoax yang merugikan diri sendiri. melakukan budaya membaca sehingga masyarakat akan selalu berhati-hati dalam mencermati berita dalam Covid-19 baik secara online maupun offline agar terhindar dari berita hoax 
yang muncul, meskipun pelaku penyebaran berita hoax telah memiliki sanksi hukum pidana di Indonesia.

\section{DAFTAR PUSTAKA}

Peter Mahmud Marzuki, 2008, Penelitian Hukum Cetakan 2. Jakarta: Kencana.

Simarmata, Janner,dkk, 2019, Hoaks dan Media Sosial: Saring Sebelum Sharing, Jakarta, Yayasan Kita Menulis.

Alief Sutantohadi, Rokhimatul Wakhidah, 2017, Bahaya Berita Hoax dan Ujaran Kebencian pada Media Sosial Terhadap Toleransi Bermasyarakat, Jurnal Pengabdian Kepada Masyarakat. Vol. 1, No. $1,1-5$.

Dedi Rianto Rahadi, 2017, Perilaku Pengguna dan Informasi Hoax di Media Sosial. Jurnal Manajemen E Kewirausahaan, Vol. 5 No. 1, 58-60.

M. Ravii Marwan, Ahyad, 2018, Analisis Penyebaran Berita Hoax di Indonesia. Jurnal Nasional. Vol. 1 No. 1, 1-16.

Juditha, Christiany, 2018, Interaksi Komunikasi Hoax di Media Social serta Antisipasinya, Jurnal Pekommas. Vol. 3 No. 1, 31-44.

Hamalatul Qur'ani, Pasal Berlapis Bagi Penyebar Berita Hoax, https://www.hukumonline.com/berita/baca/lt5b051b504cf5b /pasal-berlapis-bagi-penyebar-berita-hoax/, Diakses pada tanggal 13 Mei 2020.

Menkominfo: Ada 554 Isu Hoax soal Covid-19, 89 Orang Jadi Tersangka, https://news.detik.com/berita/d4982087/menkominfo-ada-554-isu-hoax-soal-covid-19-89-orangjadi-tersangka. Diakses pada tanggal 13 Mei 2020. 
— Penyebaran Hoaks Virus Covid-19 Ditangkap Polisi, https://www.youtube.com/watch?v=2C-92kAUzaQ, diakses pada tanggal 13 Mei 2020.

Another Pastor Strikes, Makes Congregants Drink Dettol, https:/ / citizen.co.za/news/ south-africa/1371173/ anotherpastor-strikes-makes-congregants-drink-dettol/, diakses tgl 13 Mei 2020

World Health Organization, Novel Coronavirus 2019, https://www.who.int/emergencies/diseases/novelcoronavirus-2019, diakses pada 15 Mei 2020.

Undang-Undang No.1 Tahun 1946 Tentang Peraturan Hukum Pidana Undang-Undang Informasi dan Transaksi Elektronik 